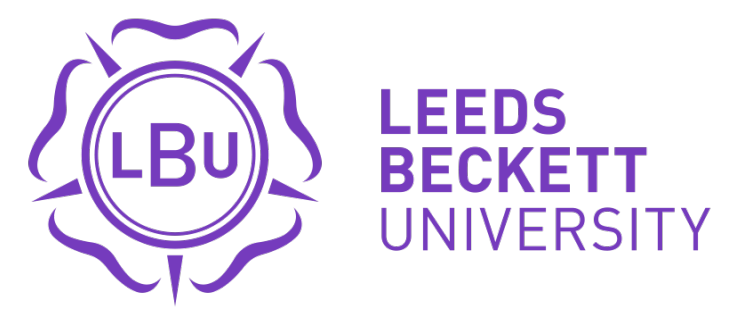

Citation:

Sparkes, AC and Stewart, C (2019) Stories as actors causing trouble in lives: A dialogical narrative analysis of a competitive cyclist and the fall from grace of Lance Armstrong. Qualitative Research in Sport, Exercise and Health, 11 (4). pp. 460-477. ISSN 2159-676X DOI: https://doi.org/10.1080/2159676X.2019.1578253

Link to Leeds Beckett Repository record:

https://eprints.leedsbeckett.ac.uk/id/eprint/5731/

Document Version:

Article (Accepted Version)

This is an Accepted Manuscript of an article published by Taylor \& Francis in Qualitative Research in Sport, Exercise and Health on 18 Febuary 2019, available online: http://www.tandfonline.com/10.1080/2159676X.2019.1578253

The aim of the Leeds Beckett Repository is to provide open access to our research, as required by funder policies and permitted by publishers and copyright law.

The Leeds Beckett repository holds a wide range of publications, each of which has been checked for copyright and the relevant embargo period has been applied by the Research Services team.

We operate on a standard take-down policy. If you are the author or publisher of an output and you would like it removed from the repository, please contact us and we will investigate on a case-by-case basis.

Each thesis in the repository has been cleared where necessary by the author for third party copyright. If you would like a thesis to be removed from the repository or believe there is an issue with copyright, please contact us on openaccess@leedsbeckett.ac.uk and we will investigate on a case-by-case basis. 
Stories as actors causing trouble in lives: A dialogical narrative analysis of a competitive cyclist and the fall from grace of Lance Armstrong

By

Andrew C. Sparkes

[Leeds Beckett University, UK]

\&

Carly Stewart

[Bournemouth University, UK]

Journal of Qualitative Research in Sport, Exercise and Health (on line first, 20019)

Correspondence to:

Professor Andrew C. Sparkes PhD

Carnegie School of Sport

Leeds Beckett University

Fairfax Building (Room124)

Headingly Campus

Leeds. LS6 3QT

United Kingdom

Email: a.c.sparkes@leedsbeckett.ac.uk 


\title{
Stories as actors causing trouble in lives: A dialogical narrative analysis of a competitive cyclist and the fall from grace of Lance Armstrong
}

\begin{abstract}
This article examines how stories as actors can cause trouble in lives by focusing on the reactions of a competitive cyclist, named David, to the public confession by Lance Armstrong of being a drug cheat and a bully. We begin by providing a context for this trouble by considering the affective dynamics of fandom and the part this plays in the social construction of sporting heroes by self and others as part of an interactive process. Next, we examine the ways in which David's narrative habitus draws him towards Armstrong's heroic story as a gift that leads him to develop a strong athletic identity as a competitive cyclist and also become a committed fan that continually denies evidence regarding the behaviours of his hero. Following this, we focus on David's emotional reactions to Armstrong's betrayal and the identity management strategies he uses to disassociate himself from his disgraced hero. The role that material biographical objects perform in this process and the affective dilemmas they pose for David over time are highlighted. Attention is then given to issues of tellability and narrative silence regarding Armstrong's story and their impact on David's family and the wider cycling community. In closing, we offer some reflections on the ways that David's story is shaped by the performative demands of specific kinds of masculinities prior to considering the narrative consequences of demonising Armstrong and making him the finalised villain of the piece.
\end{abstract}

\section{Keywords}

Stories, trouble, fandom, affect, heroes, betrayal, biographical objects, tellability, masculinities 


\section{Introduction}

According to Frank (2010) stories have a number of capacities. One of these is to both deal with human troubles and also to make trouble for humans. In view of this, he believes stories as companions that inform life can be either a gift or a danger. The notion of stories as companions also draws attention to another capacity of stories that is to effect action. As Frank emphasises, stories are not only performed; they perform, they do things, they act.

Drawing on the work of Pierre Bourdieu, the narrative habitus as described by Frank (2010) is likely to play an important role in shaping how a person reacts to any given story and how the story acts on them. This is because the development of this kind of habitus over time involves the embedding of stories in bodies in ways that predisposes one to hear 'some stories as those that one ought to listen to, ought to repeat on appropriate occasions, and ought to be guided by' (p. 53). Here, an embodied sense of attraction, indifference, or repulsion is developed that shapes how people feel in response to stories so that intuitively, and often tacitly, they sense that some story is for them or not for them by expressing possibilities of which they are or can be part, or by representing a world in which they have no stake.

The workings of the narrative habitus are often thrown into sharp relief when people encounter disturbing events that, according to Brockmeier (2017: 290) are catalytic and 'set free a meaning surplus charged with a significance and intensity that might have mounted over time'. One such event in the sporting world, and especially the competitive cycling community, was the television interview Oprah Winfrey conducted with American cyclist Lance Armstrong in January 2013. Winfrey opened the interview with a series of questions, to which she requested 'yes' or 'no' 
answers from Armstrong. Asked if, during his seven consecutive wins of the Tour from 1999-2005 he used banned substances to enhance his cycling performance he said: 'Yes.' Asked if he ever blood doped or used blood transfusions to enhance his performance, he replied: 'Yes'. Asked directly if he was a bully Armstrong replied: 'Yes.'

In this interview in front of millions of viewers, and after years of media speculation and robust denial on his part, Lance Armstrong confessed to being a drug cheat and a bully. He stated 'I view this situation as one big lie that I repeated a lot of times,' and he also acknowledged that his fans had 'every right to feel betrayed.' Thus was the myth of this sporting hero shattered once and for all and the rapid fall from grace of Armstrong was initiated in which not only was his celebrity public self unravelled via a process of status degradation, but he was also transformed overnight from hero and role model to villain (see Yar, 2014).

For some, this public confession let loose a dangerous story full of trouble. This was particularly so for those cycling fans that had formed strong affective attachments to, and made significant affective investments in Armstrong as the modern embodiment of a sporting hero capable of influencing their own lived experiences and daily practices. In his thought provoking autoethnographic account of performing affective fandom in relation to the Formula One driver Jacques Villeneuve, Sturm (2011: 225) notes that a key feature of the fan, or fandom, is the intense relationship that they have with the media, 'shaped through their engagement with texts, famous individuals and their array of consumptive and/or performative practices'. In support of this, Sandvoss (2005: 8) defines fandom as 'the regular, emotionally involved consumption of a given popular narrative or text, such as a media-specific text or other popular texts such as sport teams or star 
athletes as hero/heroine. For Sturm, the notion of fan 'intensity' can be usefully understood through the concept of affect.

In particular, affect offers a vocabulary for articulating the attachment to and investment in media objects/texts by fans, the affective relationships and practices fans engage in, and the temporal, spatial and embodied dynamics which underpins the intensities of such investments ...Central to notions of affect are investments (the caring or passion for something), mattering maps (how individuals chart their investments and make particular things 'matter') and intensity (literally the energy or intensity of the investment). (Sturm, 2011, $\mathrm{pp}, 225-226)$.

Related to the above, Kelly (2015:317) notes that being a fan can produce 'intense states of joy and suffering, gratification and grief, pride and shape, intimacy and relief.' Likewise, with regard to conceptualising fan commitment Hall, Shearer, Roderique-Davies, Mayer and Hall (2012) talk of affective loyalty that is characterised by fans having a strong emotional attachment that increases their psychological resistance to change and any form of conflicting information about their team.

The notions of affective attachment, investment and loyalty, mattering maps, and intensities noted by Hall et al (2012) and Sturm (2011) has clear links with the affective dynamics of the narrative habitus as described by Frank (2010) in relation to how people feel in, and through, their bodies about the repertoire of stories made available to them by the cultures they inhabit and also how such stories perform as actors in their lives. One such story that circulates within Western cultures and 
invites affective attachments, investments and loyalties, as we indicated earlier, is that of the sporting hero, a figure that we now consider.

The concept of the athlete as hero (and role model) along with debates over their nature and purposes has been with us since the time of the ancient Greeks. In view of this, Gammon (2014: 247) notes that the qualities of heroes are inherently difficult to define with precision because the 'choice and depiction of heroes is culturally framed, as heroism is always measured and (re)evaluated against the societal values of the day '. He further emphasises that when it comes to evaluating the deeds attained by the sporting hero, context is everything. Thus, while winning the Tour de France in 1999 was enough to separate Lance Armstrong as a rider from the simply talented or gifted, to win it having in 1996 been diagnosed and successfully treated for Stage 3 testicular cancer was extra-special in terms of media attention. This comeback as a cancer survivor was a pivotal moment in his elevation to heroic status within the sporting world that was gradually solidified as he went on to win the Tour another six times.

According to Yar (2014: 9), 'sports stars are themselves far from passive in their transformation into celebrities and icons'. He notes that no sporting celebrity's public profile is complete without a visible commitment to a charitable endeavour, or even better their own charitable foundation. Such commitment, Littler (2008: 237) argues is a way for celebrities to appear to raise their profile 'above the zone of the crudely commercial into the sanctified, quasi-religious realm of altruism and charity, whilst revealing or constructing an added dimension of personality: of compassion and caring'. Significantly, Armstrong founded his own cancer charity named LiveStrong in 1996 following his own encounter with this disease. 
As part of his self-narrative, the founding of his cancer charity along with his 'journey back to life' by 'beating' cancer and winning his first Tour de France was elaborated and celebrated when in 2000, aged 28, Armstrong published his autobiography entitled It's not about the bike: My journey back to life. This became an international bestseller and won the William Hill Sports Book of the Year. On the back book cover it states, 'Lance Armstrong's story is extraordinary and inspirational.... an awe-inspiring tale of immense courage and will.' As a narrative type, Author (date) suggests, this autobiography can be classed as a 'romance' in which the hero faces a series of challenges en route to his goal ('beating' cancer) and an eventual victory (making a comeback and winning a major event). The essence of the story is the struggle itself in which, as Lines (2001) notes, the necessary characteristics of strength, toughness, bravery, courage, determination, integrity and competitiveness required of the male sporting hero are displayed. This romance narrative is further embellished in a follow-up autobiography in 2003 entitled Every second counts: from recovery to victory. Here, Armstrong presents himself as being anti-drugs and a clean athlete. In these two autobiographies, Yar (2014: 10) notes that Armstrong managed to 'skilfully weave together different narrative threads (world-beating athlete, cancer survivor, humanitarian, loving family man) into a seamless story of heroism and virtue'.

The weaving together of similar narrative threads around Armstrong is also evident in Rusu's (2013) media discourse analysis of how he was reported in the New York Times between 1991 and 2010. This analysis reveals that Armstrong was portrayed as a mythical hero who through individual sacrifice, perseverance, dedication, and a fighting spirit was victorious not only in the battle with the mountains of the Tour de France, but also in the fight against cancer. Rusu argues 
that as a character imputed with extraordinary and almost supernatural powers that managed to overcome the human condition, Armstrong gets placed in the 'category of those who go above the ordinary, of those who manage to overcome death' ( $p$. 542). Positioned in this way, Rusu suggests that Armstrong was living proof of the traditional hero myth circulating within the media that operated to provide society with an inspirational and exemplary model for everyone to follow and live by in the pursuit of success. Adding to this, in his consideration of totemic sporting heroes, like Armstrong, Gilchrist (2006) notes that such athletes become objects of reverence. In this process, as Cubitt (2000: 3 ) observes, they are endowed with a 'special allocation of imputed meaning and symbolic significance - that not only raises them above others in public esteem but also makes them the object of some kind of emotional investment'.

Against the backdrop provided above, it is likely that Armstrong's public confession became a source of trouble for those fans whose narrative habitus had attracted them to his heroic narrative and who had developed strong affective attachments to and made substantial affective investments in him as a mediated object of reverence. This raises questions about how Armstrong's story as an actor does things and works for and on such people in their lives in relation to how they interpret, respond to, cope with, and resolve the narrative trouble instigated by his confession and subsequent fall from grace. To address such questions, in this article we focus on the case of a successful cyclist and self-declared Armstrong fan named David (a pseudonym), and his relationship with his sporting hero both before and after the Winfrey interview.

\section{Methodology: Thinking with and about David's story}


David, a mature student, came know to Author $\mathrm{X}$ when she taught on a module that he had opted for at their university. It became clear that he had a strong interest in Lance Armstrong. Author $\mathrm{X}$ therefore invited David to share his views about Armstrong with her in a series of interviews. He readily agreed to do so. Given the power differentials that existed between David as a student and Author $\mathrm{X}$ as a lecturer it was decided to conduct the interviews after the taught module was finished so that they were not then involved in an 'official ' student/lecturer relationship. Also, it is important to note that Author $\mathrm{X}$ had no part in the assessment of the module and so this further reduced the power dynamic between her and David. Finally, it was agreed that no publication using data from the interviews would take place until after David had completed his degree and left the institution.

Following university ethical approval, six hours of interview plus follow-up conversations took place at a time and place convenient to David. These interviews were conducted in 2015, were recorded and transcribed verbatim, while issues raised in follow-up conversations were noted in a field diary. In the first instance, the transcripts were read multiple times by Authors $X$ and $Y$ with a view to thinking with the story told by David. For Frank (2013:158) thinking with stories 'means joining with them, allowing one's own thoughts to adopt the story's immanent logic of causality, its temporality, and its narrative tensions....The goal is empathy.'

Have conducted multiple readings individually, we then shared our thoughts and feelings regarding David's story. Here, we both reacted to the emotionality of the unfolding story told along with its temporal dynamics that moved from the joys of hero worship to the pain of betrayal. From the process of thinking with David's story, a structural analysis emerged. Such an analysis, Riessman (2008) notes, focuses on the telling rather than the told in order to reflect on how the story is organised and 
put together to form a specific plot-line. Alongside this, we shared our thoughts on the keys issues and moments contained in the story. This led us to consider the content of what was said as is customary in a more traditional form of thematic analysis.

Given our interest in stories as actors that do things, we also engaged with the kind of dialogic/performance analysis described by Riessman (2008). For her, this is a broad and varied interpretive approach to oral narrative that makes selective use of elements of both thematic and structural analysis but adds other dimensions. In relation to this approach, Frank (2010) notes that dialogical narrative analysis studies the mirroring between what is told in the story - the story's content - and what happens as a result of telling that story - its effects. In this process, he points out the following.

The balance between story content and its effects is rarely even; some analyses lend themselves more to one side than the other. But the mutual dependence of content and effects can never be forgotten, whichever is foreground or background' (Frank, 2010, p. 72).

If method is taken to be a prescribed set of steps that an analysis should follow, then both Frank $(2010,2012)$ and Riessman (2008) emphasise that there is no one method of narrative analysis. Refusing such an approach, Frank (2010) makes the point that in terms of dialogical narrative analysis, any notion of method needs to be seen as that which initiates a movement of thought that invents, makes use of, and modifies conceptual tools as they are set into a relation with specific practices and problems that they themselves help to form in new ways. To help initiate such movement of thought and open up analysis in relation to story telling practices, Frank 
(2012: 46-47) proposes an open-ended set of questions for consideration. These are as follows.

- Resource questions: What resources shape how the story is being told? How are narrative resources distributed between different groups; who has access to which resources, and who is under what form of constraint in the resources they utilize?

- Circulation questions: Who tells which stories to whom? Who would immediately understand the story and who wouldn't? Are there some people you wouldn't tell that story to, and why not?

- Affiliation questions: Who will be affiliated into a group of those who share a common understanding of a particular story? Whom does the story render external or other to that group? Who is excluded from the 'we' that share the story?

- Identity questions: How does the story teach people who they are, and how do people tell stories to explore whom they might become?

- What is at stake questions? How is the storyteller holding his or her own in the act If telling that particular story, in that way? How do the stories that some people have available convince them of what they have to do and to be in order to hold their own?

Such questions assisted our movement of thought regarding David's story and this, in turn, led us to act as conceptual bricoleurs in constructing our layered and necessarily multi-disciplinary interpretations. According to Denzin and Lincoln (2011: 4) the qualitative-researcher-as-bricoleur uses the 'aesthetic and material tools of his or her craft, deploying whatever strategies, methods, or empirical materials are at 
hand'. Importantly, they note that the choice of which interpretive practices to employ are not necessarily set in advance. This view sits well with the kind of dialogical narrative analysis described by Frank (2012) that is an iterative process.

The analysis of the selected stories takes place in attempts to write. The research report is not post hoc to the analysis that is completed before writing. Rather, reports emerge in multiple drafts that progressively discover what is to be included and how those stories hang together...Decisions are constantly made about what belongs in this representation, what should be set aside for later, and how the stories fit together - that's analysis. (Frank, 2012, pp. 43-44)

Accordingly our analysis began with our attempts to compose David's story based on what he shared in interviews. The various concepts we then used to interpret aspects of this story, such as tellability, narrative silence, and the significance of material biographical objects emerged from our various readings of the story and feedback we received on those readings. For example, both of the QRSEH Reviewers of an earlier submission of this article expressed the view that our representation of David's story made him appear rather naïve and gullible regarding Armstrong and that we did not provide enough context for why this might be so. This stimulated us consider the notion of fans/fandom and the literature on this topic that illustrates how fans make significant affective attachments to, and investments in their sporting heroes in ways that can prevent them from seeing anything 'bad' about them whatever evidence is provided. This move, then led us to reconsider how we had conceptualised the contexts in which the sporting hero is constructed by self and others via the media as an object of reverence and loyalty that invites and sustains such affective attachments and investments. All of which resulted in a major 
revisions to the introduction of this article and to various sections within it.

The iterative and accumulative process described above are an important feature of dialogical narrative analysis that seeks to encourage further dialogue with the story as told, by enabling others to retell it in varied ways so as to create new connections and representations. As Frank (2012) states:

The dialogical analyst freely admits that the collection could be assembled and sorted in multiple ways, yielding different analyses; doing those other analyses would expand the dialogue. Dialogical analysis has no interest in presenting itself as the last word. What requires exclusionary gestures is unclear at best and suspect at worst. Part of what makes a dialogical report good is the opening it creates to further representations. (Frank, 2012, p. 44)

Besides our analysis seeking to expand the dialogue around David's story and opening it up to create further representations, we would also offer the following goodness criteria for use in the spirit of an open-ended list as suggested by Author (date). Tracy (2010) speaks of rich rigour that can be generated through using a requisite variety of theoretical constructs in a flexible manner to engage with the phenomenon under study. For her, 'a researcher with a head full of theories, and a case full of abundant data, is best prepared to see nuance and complexity' (p. 841). In terms of rigour, Tracy also notes that for this to be achieved there needs to be enough data provided in the report to support significant claims, and the context or sample should be appropriate given the goals of the study. This fits in with the criteria of width and comprehensiveness of data advocated by Lieblich, TuvalMashiach and Zibler (1998: 207-208) for whom 'numerous quotations in reporting narrative studies, as well as suggestions of alternative explanations, should be 
provided for the reader's judgment of the evidence and its interpretation'.

With regard to narrative studies, Lieblich et al (1998: 173) also offer the criterion of coherence that involves 'the way different parts of the interpretation create a complete and meaningful picture'. They note that this from of coherence can be evaluated both internally, in terms of how the parts fit together, and externally against existing theories, concepts and previous research. Finally, with regard to achieving credibility, Tracy (2010) suggests that one of the most important means of achieving this is via thick description. By this, she means an in-depth illustration that explicates culturally situated meanings by providing abundant concrete detail. Such thick description, as we have provided below, enables readers to reflect on David's case and make connections where appropriate to their own situations or studies prior to forming the various forms of generalisations described by Smith (2017), such as, naturalistic generalizations and transferability.

With the above methodological issues in mind, we now turn our attention to David's story about his relationship with Lance Armstrong prior to and after his confession and consequent fall from grace.

\section{Beginnings: The call and Armstrong's story as a gift}

As a schoolboy, David's sporting interests lay in football and he was good enough to be considered by a professional club. Throughout this time, his grandfather who had been a competitive cyclist in his younger days and a lifelong cycling enthusiast often offered to take David out cycling but he expressed no interest in doing so.

David remembers this grandfather always had the cycling on the TV during visits to his house and that if there was an exciting sprint finish he would sometimes 
watch the end of the race but 'that was about it.' Here, at best, David offers professional cycling what Sturm (2011) describes as a distracted glance. He vividly remembers, however, the moment this distracted glance began shifting towards a more focused and intense gaze. This was the day his grandfather called out to him to come and watch Lance Armstrong in the 1999 Tour de France.

'Come on, look at this, come and see this guy. There's this man beating the one in yellow. He's just recovered from cancer and he's winning this race!' l'd say 'What do you mean?' because you hear about cancer a little bit at that age, you know it's really bad and you think if someone has cancer they die. You think 'That's unbelievable.'

The Tour de France is a profoundly mediated sport and, for most of its global audience (e.g., David and his grandfather), is experienced primarily through its televised coverage (see Sturm, 2011). In this first instance, David is attracted to Armstrong as a media object by the cancer survivor plot line his grandfather articulates about him as an athlete who having 'beaten' his illness and is making a heroic comeback to win a major sporting event. The 'comeback' aspect of Armstrong's story is particularly appealing to athletes because it resonates with the restitution narrative described by Frank (2013). With its hope of a restorable bodyself this is the narrative that many athletes would like to have as their companion should they experience serious illness or injury and their narrative habitus draws them towards it (Author, dates).

Even though David's narrative habitus predisposes him towards the restitution aspect of Armstrong's story, and even though his grandfather provides a narrative environment that encourages David to be interpellated (Althuser, 1971) into 
it, at this early stage David has yet to do so. Over the years, however, the call of Armstrong's story gradually increases in strength as he continues to win the Tour de France year after year.

So anyway, he won his first Tour de France, again nothing, I just took a bit of interest, but nothing too major really. I just remember then, like going there a year later (to his grandfather's house) and he said 'Oh, that guy - he's going to win this race again!' And this goes on and after like the third time he wins, you start to become a bit like 'Oh my God! This guy is incredible!' So a year later you make a point of actually sitting down to watch the entire thing, to see him win it. And it just went from there. Then, I was coming to 17 , and he was going to win about his fifth Tour. That's when I thought, 'Wow! This guy is incredible!' Then I was making a point of watching the Tour de France and it came to the point when I asked my Grandfather, 'Can I have a go on your old bike?' Then it went from there. That's when I started cycling.

On taking up cycling just after Armstrong retired for the first time in 2005 (he made an unsuccessful comeback in 2009 and retired for a second time in 2011), David read Armstrong's (2000) autobiography that led him to define Armstrong as his 'real life superhero.' Inspired by this story line, David began to invest heavily in physical, affective and financial terms in this sport. As he puts it:

It just started off as a bit of a fan, a bit of riding, then it got more and more serious and you get to the obsessive stage! I started to get more and more obsessed with it and looking more into idols - you follow other cyclists and you wonder what it's like with this Armstrong and you start buying all his DVDs. 
This identification with Armstrong gradually developed as David began to purchase and wear cycling clothes endorsed by Armstrong and bought an expensive racing bike. As he gained increasing success in competitions this solidified his core athletic identity as a cyclist. According to Brewer, Van Raalte and Linder (1993) athletic identity is the degree to which an individual identifies with the athlete role. Lamont-Mills and Christensen (2006), note that as a social role, athletic identity develops as a response to group affiliations and social interactions while as a cognitive schema, it is the means by which individuals interpret information and behave according to the conventions of the athlete role. They point out that athletic identity is best viewed as a multidimensional construct that encompasses social, cognitive, and affective elements. This is confirmed in the following statement where David reflects on starting his university degree in his early twenties:

I became friends with Jack (another competitive cyclist) and people like that in university, because when I first came here you were weird if you were a cyclist. But straight away he knew where I was because I wore a Lance Armstrong top to the gym and only a cyclist would really know 'Oh, he must be a cyclist if he's wearing that.'

Regarding the significance of consumption in fan practices and performances, Crawford (2004: 114) notes that sport-related goods allow fans to 'display their identity and membership to a particular supporter community,' and that such consumption plays an important role in how they define and make sense of their 'self', as well as distinguish our 'self ' from others. As if to parallel David's behavior, Sturm (2011) explains the significance of him purchasing a British American Racing shirt to add to the Jacques Villeneuve cap and t-shirt he was wearing prior to attending a race where his hero is competing. 
Procuring and displaying authentic team gear operates as a symbolic marker; signifying an economic status (the expense of the item), in addition to a social distinction based on perceived social status and worth. There are clearly also performative and narcissistic dimensions to this self-reflective display of self to others too, reinforcing how consumer goods are used to associate the fan-self with his/her particular object(s) of fandom. (Sturm, 2011, p. 233)

As indicated in his earlier comments, at this stage David was proud to be associated with the Armstrong myth and brand. He was happy for his purchase of consumer goods to display his commitment to Armstrong and for these goods to be used as a marker of social differentiation and distinction with his student colleagues. Here, the Armstrong story is taken as a gift, performing itself both on and through his body and becoming a material semiotic companion in his life. Significantly, as a traditional hero myth this story was providing him with a narrative map regarding not just how to be a successful cyclist but also a moral person.

He didn't just teach me cycling, he almost taught me how to be a person. I wanted to be like him. You think 'Oh, I want to be like that. He's a good role model. He seems like the ideal father, perfect husband...And I think people who feel like me, they see it that he was a role model for them; not just a cyclist. You think you've got to become this fighter who got over this cancer, but that's nothing to do with cycling, that's an image of the person he is and you think 'I want to be this person!' It's just - he is a real life superhero, like I kept saying.

The phrase 'like I kept saying' is revealing. During is time at university, David found himself continually defending his hero to fellow students as rumours of Armstrong's 
use of performance enhancing drugs and his bullying of team mates began circulating and intensifying in the media. As Yar (2014) points out, since his first Tour win in 1999, persistent rumours and accusations circulated about failed doping tests whose results had been suppressed, claims were made by former teammates about his involvement in doping, and suspicions raised about his long-standing relationship with notorious Italian 'doping doctor' Michele Ferrari.

Armstrong emphatically denied all wrong-doing, and successfully sued The Sunday Times for libel after sport journalist David Walsh accused Armstrong of doping. In 2012, USADA (the US Anti-Doping Agency) published its report on a two-year investigation into the US Postal Service team, and concluded that Armstrong had doped and trafficked drugs. He was banned for life from all WADA-regulated sports, and the UCI (Union Cycliste Internationale) striped Armstrong of his seven Tour de France titles. (Yar, 2014, p. 33).

David would have been aware of all the events described above. In the face of such evidence many cycling fans would have concluded that Armstrong was indeed a cheat. This was clearly not so for David. His narrative habitus coupled with his affective attachment to, investment in, and loyalty to Armstrong as his sporting hero meant that such negative tales were viewed with suspicion and the facts presented were dismissed as part of a 'conspiracy' by those jealous of his success and not worthy of attention (Hall et al., 2012; Sturm, 2011). Linked to this, is the power of long distance love (LDL) as articulated by Farred (2002) to account for his relationship with Liverpool Football Club. For him, the notion of fandom does not suffice to describe his emotionally invested relationship with this club because LDL is what happens when you over-identify in an act of 'enduring love, blind, rock-solid faith, and abiding passion' (p. 10). 
David's unwillingness and/or inability to face the facts about Armstrong's use of performance enhancing drugs may also relate to the strong athletic identity that he had developed over time as a competitive cyclist which was, in part, inspired by the heroic aspect of Armstrong's story. In relation to this both Brewer et al. (1993) and Author (date) note that a strong exclusive athletic identity can act as Hercules' muscles or as an Achilles Heel. As summarised by Ronkainen, Kavoura and Ryba (2016: 57), 'athletic identity can be a positive source of meaning and self-esteem, but also highly problematic for well-being when sport is not going well or the career is abruptly terminated.'

With regard to acting as an Achilles Heel, Brewer et al. (1993), Ronkainen et al. (2016) and Author (date), note how the development of a strong athletic identity can lead to emotional difficulties when athletes encounter disruptive life events. Such events include, being dropped from the team, being badly injured, reaching the end of their playing career, or in the case of David being confronted with information that undermined the affective investments he had made in Armstrong as his sporting hero and role model that he had consistently defended in public against charges of cheating. This view is supported by Lamont-Mills and Christensen (2006), who note that when those whose self-worth is defined by their sport participation are faced with undesirable sporting outcomes (e.g., the possibility of your hero being a drug cheat), they are more likely to experience these as negative and threatening events which may lead to them experiencing commensurate negative emotions. The level of perceived threat and accompanying negative emotions, are likely to be intensified when the development of such an identity is accompanied by athletic identity foreclosure. 
According to Brewer and Petitpas (2017: 118) athletic identity foreclosure refers to "commitment to the athlete role in the absence of exploration of occupational or ideological alternatives.' In such circumstances, the accusations made against Armstrong in the press and the official report made by the US AntiDoping Agency are likely to have been perceived by David as a threat to his sense of self and his athletic identity, to be defended against by refuting of ignoring this information. Such a strategy helps to explain what might seem as incomprehensible to others. In relation to this, Frank (2010: 81) talks of the power of stories and the hypnotic spell they can cast over the people that get caught up in them in ways that produce 'an embodied assent that requires the incomprehension of other stories that fail to fit the underlying narrative of one's own story.' Accordingly, athletes from the same sporting culture can live caught up in one story alongside others living with a very different story of the same event and the interpretations made of it.

All the features described above played their part in influencing the views held by David and his cycling friend as they prepared to watch the interview with Oprah Winfrey.

To the very last minute we were saying 'He is innocent. This is a big conspiracy. They're trying to ruin this man because he's too good. He's got the world's attention now, he's going to make the people who made these allegations, look fools' To the last minute! And we were just sitting there. It was almost like getting ready to watch a big football game. We had food in and this and that, because we were in this flat, and we were there all excited to see what's going on! Not like 'Oh, God. It's going to be the worst thing 
ever.' We were like, 'we can't wait to see what he's going to do. It's going to be funny!'

What Armstrong actually said was far from funny.

And when he came on straight away and the first question was 'Have you ever done drugs?' he didn't hang around he said 'Yes.' Then he literally came out with it, with no remorse or anything. And we just went ... the whole world came apart then. I think we watched the whole thing and I don't think we spoke a word all through it ... It was just a case of sheer shock ...Life was taken off you then.

For David, in this moment, Armstrong's story shifted from being an inspirational gift to a source of trouble. How he responded to this trouble will now be considered.

\section{The betrayal: Armstrong's story as trouble}

According to Yar (2014: 11), the press outrage that follows the exposure of a celebrity athletes 'exists in a symbiotic relationship with the betrayal felt by fans and followers who find that their emotional investment in the star's persona destroyed by revelations of wrong doing'. Armstrong's public confession was certainly taken by David as a personal act of betrayal. It constituted a major biographical disruption in his life leaving him affected at a deep emotional level. As he put it, 'They just think you're upset because your favourite rider has taken drugs but like I said, there's a lot more to it than that.' In trying to explain how he felt about this betrayal David often likened it to the break up of a love affair:

I thought you were an amazing guy when you were just a liar and a cheat all

the time. I hate you and I want nothing to do with you!' That's kind of like if you 
had a girlfriend who you thought was this unbelievable person, who let you know she was amazing, and then she ended up being unfaithful. It's that kind of feeling. You can say it's sad, but if I describe it like that I think that's what most people can relate to.

Describing his emotional reaction to this break-up David explained that 'there was no crying but there was a lot of sulking. Just lifeless and really miserable.' This misery was intensified when he became ill with glandular fever, could not train, and seriously considered giving up competitive cycling. He acknowledges the impact that Armstrong's confession had on his deliberations at this time and how it had impacted on others who had consequently decided to give up this sport.

Again, I don't think that's something he realises. He sees himself as this kind of immortal, great, person who's done these great things in cycling. l'd love to just say to him 'Do you realise how many people have just given up something they love because of the hurt from you?' ... Some people have taken it a lot worse than I have. There are other guys who never ever touched a bike ever again. So imagine what it would be like talking to them.

David's misery involved him having to deal with what Goffman (1959) describes as a spoiled identity as a former Armstrong fan and advocate. He recalls, members at the university gym saying, 'See, we always told you he was a druggie.' To cope with this situation, and to publicly signal that he did not support or condone Armstrong's actions, David adopted a number of Goffman's impression management strategies in order to dissociate himself from his disgraced hero and the stigma attached to him. The most immediate was to stop wearing any of the clothing he had purchased that would associate him with Armstrong. 
I would never wear his cycling kit any more because there is a bit of stigma to that ... If I was out riding and a group of people who know me and know I've done well and they know my grandfather, he's got a lot of respect, they'd be 'Why's he still wearing Lance Armstrong kit? Does he think it's all right, what he's done?' ... Because you have the people who think he's still great, they don't care what he's done, and they'll still wear his kit out cycling. But when you are cycling you're most or less representing the hard core cycling group, not just the general people you see in the gym. So that stuff has just been discarded, I would never wear it ... If I look at a t-shirt, I just go like that (does a throwing away action with hands).

Other biographical objects acting as identity markers in the private domain that were associated with Armstrong were also discarded or hidden from view.

It's not just the kit you'd wear, there were DVDs, books ... It's weird because I've discarded everything. Not to the point where I've thrown out the books, they're in a box, because I don't want people walking into my room to see them ... because I think a lot of people come in and see what books you read, and they can see what kind of person you are. If I walked into your house and saw what books you had it would give me an idea of the type of person you are, I think. So I wouldn't want people to see that, so they're boxed up.

In contrast to books and sportswear, one biographical object remained problematic for David in terms of how it worked to position him in relation to his younger past self as an Armstrong fan and his current self as someone whom Armstrong betrayed. This was a large framed poster made up of seven photographs 
of Lance Armstrong in the process of winning his seven Tours that still hung above David's bed at his parent's house. In relation to his former self he recalls:

So it was a really inspiring picture and I used to love having it above my bed, and if I ever had visitors I used to be quite proud to show it to them 'this is my hero' and they'd say 'Wow! That's quite an incredible picture.' If I was having a bad day l'd just look at this picture and think 'No go on, you can see him suffering in these pictures.' So out of all my things that is the one that had the most effect because it is a really good picture.

In contrast his current self views this poster as follows, 'Now, I look at it and I think "I'll take it down, or l'll throw it away" and now I'm obviously really angry with everything that's gone on." Yet the poster remains above his bed. Explaining why this is so, David expresses the mixed emotions attached to this significant biographical object in his life.

I went to take it down one day, I was going to throw it away and re-use the frame. But then I thought 'I can't throw it away. Because even though I hate the guy now, I thought that poster at the time was really inspiring for me.' And I hate myself sometimes for thinking that, because I'm one of those people who say now 'Oh, he's dead to me, blah, blah, blah.' But that one picture, that's the only thing that sometimes I think 'No, I remember the days when I would wake up and think 'I'm not going on my bike today. No way.' And then l'd look at that and it'd be 'Oh come on, you can do it.' And then there'd be days when l've come home from 7 hours of riding on my own in the rain and you come in like a drowned rat and you'd go in your room and you're thinking 'Why do I do it?' and you look at stuff there and you think 'Oh, go on, he does 
it.' ... So yes, this picture is the only thing I haven't really brought myself to box up or throw away. I don't look at it now and get all inspired by it. Now I just look at it every time I go home and think 'Oh, God.'

The comments made above by David about the role that training clothes and books played in the impression management strategies he chose to present himself to self and others, and the emotional dilemmas he encountered with the Armstrong poster, signal the centrality of biographic objects, or things, in the lives of people and the telling of stories. Anthropologists have long recognised this fact and Atkinson (2017: 136) points out that 'materials, goods and artefacts have been at the heart of ethnographic fieldwork since its earliest days'. For example, Hoskins (1998) in her ethnographic work with the Kodi people of Western Indonesia quickly realised that she could not collect separately the life histories of persons and the histories of objects. This was because for the Kodi, people and the things they valued were so complexly intertwined that they could not be disentangled. Her study reveals how the meanings associated with biographical objects can be transformed over time, and that the lines between persons and things can get blurred and shift, especially when so-called inanimate objects become endowed with the qualities of persons. Thus, the usual boundaries between persons and objects are transgressed as certain objects become seen as surrogate selves

More recently, with specific reference to the significance of material objects in sporting practices and identity formation, Chamberlain and Lyons (2016) acknowledge that given their rich meanings, coupled with their symbolic and metonymic functions, material objects have the potential to invoke memories and to memorialise in ways that illuminate the entanglement of material objects with subjectivities, stories and social relationships over time. In relation to this Humphries 
and Smith (2014) speak of object biography. Here, objects (e.g., sports clothing, the Armstrong poster), like people, are considered as having mutual and multiple biographies with their use and function changing over time (e.g., before and after the Armstrong confession) and context (e.g., the public space of the university gym or the private space of the bedroom). This, in turn, changes their relationships to people and the stories they tell to others and to themselves.

With regard to the role and function of material objects in relation to David's story, proponents of what has been called the 'New Materialism ' raise some interesting issues. In her reflections on this movement, Fullagar (2017) notes that it holds to the ontological assumption that our embodied experiences are entangled with other humans (e.g. Armstrong, David's grandfather, members of the cycling club), non-humans (e.g. the university gym, David's bedroom) and objects (e.g. the Armstrong poster). For her, therefore, there is a relationality of objects, non-humans and humans that is premised upon co-implication, rather than an interaction of separate phenomena. This view is echoed by Monforte (2018: 380) who argues that a relational ontology leads new materialist scholars to assert that 'matter is to be studied not in terms of what it is (i.e. essence), but in terms of what it does, that is, in terms of its capacities to act and affect (i.e. agency).' Here, the notion of matter, or things, as passive and inert, requiring external (human) agency to do anything, is rejected and replaced by the view that not only humans but also non-humans (both organic and inorganic) have agentic and performative capacities. Accordingly, for Monforte, non-humans (e.g., a racing bike or a room) are considered active participants or actors in the process of worldly becoming as they too perform actions, produce effects and alter situations. 
The various views expressed above can all find their expressions in ways that material objects are inter-woven, entangled and enmeshed in David's story as powerful actors that are not just passive but active, and perhaps agentic, in shaping not only what is told, but how it is told, where, and to whom in varying sets of circumstance. All of which supports Frank's (2010) proposal that stories are best thought of a material semiotic companions that do things, that shape and are shaped by people via a process of progressive coevolution. For him, therefore, stories not only work with objects but stories also take the form of objects, which are known as materialised stories that have agency in affecting how we think and live our lives.

\section{Tellability and narrative silences in relation to the Armstrong story}

As hinted at earlier by David when he differentiated between his hard core cycling colleagues and the general people he met in the gym, depending upon the situation and the audience, some stories about Armstrong are more tellable than others. For Ochs and Capps (2001) tellability is one of the gradient dimensions of narrative and is something negotiated by the teller and listener in particular local contexts. In such negotiations, informed by their narrative habitus participants draw upon a repertoire of stories that they recognize and share prior to displaying their competence to use this repertoire by knowing, for example, what story fits what occasion, who wants to hear what story and when, how to react when a story of a certain kind is told, and predicting how others might react to a story that might be told.

Relevant to David's relationship to various Armstrong stories is Norrick's (2005) two-sided notion of tellability that encompasses the familiar lower-bounding side of this phenomenon as sufficient to warrant listener interest, and the generally ignored upper-bounding side where tellability merges into the no longer tellable 
because they are too personal, too embarrassing, or too troubling: Significantly, nontellability results in narrative silence.

Throughout his interviews, David often referred to one form of story about Armstrong that, in terms of his narrative habitus and strong athletic identity, he was not prepared to tell, listen to or be guided by.

I'm not one of these people who say 'Oh, well you've got to respect him, he won anyway.' And all these people who say 'Oh well, they were all on drugs! So he was best of all the druggies.' I hate that! That drives me nuts ... And I hate it when they go 'Oh well, they were all on it. So the one cheat just beat another cheat.' And you say 'Well, what about that clean guy - the first guy, the highest placed guy who didn't cheat? If all you were got rid of, he would have won.' ... I think for someone to say 'Oh, everyone was on it and it was the best of the cheats' is really naïve and a bit disrespectful to all those other men. So, that drives me mad. I can't see the logic behind that at all... I just can't justify people saying 'Oh, he's the best of a bad bunch, he's still all right.'

For David, this storyline was one he most often heard from members of the general public. At first, he opted to challenge this view directly but found the arguments that followed too predictable and emotionally draining so he decided not to engage with people on this issue. In making this choice he opted for a form of selfimposed narrative silence. Other forms of narrative silence operated in different contexts and with different audiences such as his family members and other competitive cyclists. With regard to the former, David comments as follows about what became unsayable and untellable in conversations with is Grandfather. 
They understand how much he meant to me. My grandfather and me, all we ever talk about is cycling, we don't talk about anything else. And I don't think we've ever spoken about it. It's just been a case of 'We'll pretend that never happened.' I think one time, straight after, he said 'Unbelievable about Armstrong wasn't it? I thought he was the one who would never take the drugs. Obviously they're all on them.' And I was like 'Yeah, yea,' just moping. And that was it. And yet we talk more or less every other day, it's always about cycling. So you can imagine, that's a lot of time talking about cycling, and we've never, ever mentioned it...So we went from talking for about six hours straight about this superhero, to we've never mentioned him since, ever. Which is crazy!

Likewise, David's parents understood not to raise the Armstrong 'issue' in conversations with him. As he puts it: 'My parents just treat it like an ex-girlfriend. Your parents would never talk to you about how amazing an ex-girlfriend was would they. They don't mention it.' The ex-girlfriend scenario, as a source of collective hurt, is also used by David as a reason for the self-imposed narrative silence about Armstrong within his cycling community.

For a lot of guys, hard-core cyclists, it really hurt. These are grown men twice my age, and they're hurting. They really are...Just people who thought 'Wow! This is incredible!' and they've all felt the same and they're all hurt by it really. It's like I said, it's like you wouldn't go up to your best friend who you haven't seen for six months and say 'Oh! Remember your ex? She was amazing, she was! You were silly for getting rid of her, weren't you? What were you thinking?' You wouldn't do that. It's like that really, you wouldn't go up to another cyclist 'Hi, Chris, how's things? Remember when we used to worship 
Lance Armstrong?' ... It's almost as if they don't want to openly admit it. With a lot of them, it's just really that it still hurts.

As signalled above, the self-imposed narrative silence regarding discussions of Armstrong among hard-core competitive cyclists involves the avoidance of issues relating to emotional pain and hurt. An understanding of the need for and nature of this silence regarding emotionality as a form of embodied tacit knowledge is acknowledged by David to be a marker of affiliation and competent membership within this group

Two cyclists would never get together to actually chat about Lance Armstrong. Everyone just likes to pretend it never happened. It's one of those things like 'Yes, we both know it happened, but we'll pretend it never did.' ... If you hear two cyclists loosely talking about Armstrong you'll know he clearly wasn't a hero to them, because it would be like too personal otherwise ... In cycling it's an unwritten rule - you don't talk about work, and you don't talk about Lance Armstrong. We all know it happened, but we'll pretend it didn't. And it's usually just a look that will signify that, to stop talking really.

According to David, novice competitive cyclists can be identified by their lack of mutual understanding and tacit embodied knowledge in social settings after races by the subjects they raise in conversation.

If you do get someone who's a bit naïve, who wasn't into cycling when this went on, so Lance Armstrong doesn't really mean to them what he does to you. They're not being horrible, but they're in a room after a race and just making general chit-chat and went 'Oh, did you see about Lance Armstrong on the news?' They might not realise it, so they might chat to someone else 
about that and you'll just find everyone else will move out of earshot. It's quite weird, if you were to sit there watching, you'd think 'Oh my God, they've literally just moved away and formed another conversation over there!'

The literal movement away from a story being told in the physical space described above by David is an interesting example of the embodied sense of repulsion in action that many hard-core cyclists feel in relation to a story representing a flawed and discredited world in which they have no stake or desire to engage with. This avoidance of certain stories in physical space coupled with an imposed narrative silence meant that David, was unable to publicly emote the hurt and angst that he felt in relation to Armstrong's betrayal. When asked if had talked to anybody about the feelings he had mentioned in his interview, David responded as follows:

No, because you think Joe Public's going to be an idiot about it. So can't you talk to one of your cycling friends about it? It's like, 'No, they don't want to talk about it, they just want to pretend it didn't happen.' No guy, especially young males as well, they're not going to sit there and talk about feelings, that's never, ever going to happen. So there's literally, no one who you could really chat to about it.

Significantly, it would appear that the interview situation that David found himself in as part of this study provided him with a safe and non-judgemental space in which to share his feelings for the first time.

I was walking over here (to be interviewed) and thinking 'I don't think I've ever had an in-depth conversation with anyone, a proper one about how I feel'. I've had arguments ... Obviously l've spoken to Jack (a close friend and fellow competitive cyclist), but not for a long time, but again we never had an in- 
depth conversation ... I don't know. It's weird. I was thinking I've never, really, actually talked to anyone.

This is a worrying admission by David given that these interviews took place two years after the Armstrong interview with Winfrey.

\section{Reflections}

We have illustrated how, for David, the Lance Armstrong story as a companion has acted as both a gift and a source of trouble in his life. To stimulate dialogue with David's story throughout our telling of it we have acted as conceptual bricoleurs offering multiple lenses for interpretation. Continuing in this vein we now wish to reflect on how David's reactions to the trouble caused by the Armstrong confession are framed in relation to the performance of certain kinds of masculinity and how, as part of this process, the story he constructs acts upon him to produce certain effects that are troubling for his sense of self and strong athletic identity.

In recent years, according to Anderson (2012), in Anglo-American countries the terrain of masculinity studies, the theories associated with it, and how various masculinities are performed in different contexts has shifted. For him, a significant decrease in cultural homophobia has permitted various forms of masculinity to exist linearly. He suggests that while Connell's (1995) theory of hegemonic masculinity made sense in the late 1980 s and the 90 s it currently fails to capture the intramasculine dynamics of contemporary men to whom multiple types of masculinity are permitted to exist without the hierarchy necessary in a hegemonic system. In view of this, Anderson (2009) contrasts what he calls orthodox (read hegemonic) masculinity with that of inclusive masculinity. In cultures or settings informed by the latter, Anderson and McGuire (2010) suggest that men are not only permitted increased 
social freedom in the expression of attitudes and behaviours that were once highly stigmatised, but that multiple forms of masculinity can exist in horizontal (not stratified) alignment.

Given the multiple masculinities now available, it is interesting to compare the story told to Author $\mathrm{X}$ by David as a remembering self in the interview setting, with the story of how his historical and remembered self reacted and coped with the Armstrong confession in settings such as the university gym or in family gatherings. Each of these, according to Gubrium and Holstein (2009) provide different narrative environments that have their own specialised interpretive demands that draw on distinctive vocabularies and forms of knowledge to particular kinds of storytelling. Thus, in the secure and non-judgmental interview setting with Author $\mathrm{X}$ that encourages tellability and allows him to talk openly about his emotions, David as a remembering self appears to draw on and perform an inclusive form of masculinity. In contrast, the narrative environments of the sports related settings described by David when he reflects on his remembered self and associated athletic identity in action, seem to encourage a performance more in line with orthodox or hegemonic forms of masculinity that, in combination, can lead to the expression of what Wellard (2009) calls an 'expected sporting masculinity.' Significantly, he suggests, with this kind of masculinity it is expected that painful emotional experiences are controlled by the individual concerned and made invisible, untellable and subjected to a narrative silence.

Speaking of narrative silence, untellability and invisibility in men's accounts of coping with stressful life events, Schwab et al. (2016: 289-290) note that the latter term refers to the 'absence or deficiency of communication to another person about how one is thinking, feeling, and reacting to such events'. For them, men often 
confront gendered norms surrounding emotional disclosure and they have to negotiate what Schwab et al. call hegemonic masculinity in relation to stressful life events and decide if, how and when to disclose their feelings to others (visibility) or not (invisibility). In such negotiations, as Walton et al. (2004) have pointed out, emotions and male emotional expression are constructed as being highly dependent on the object, source or context. In their analysis of men's talk about emotions, they found that their participants constructed themselves as emotional beings only within specific, rule-governed contexts that gave permission for the understandable expression of grief, joy and anger. As evidenced above, in contexts framed by notions of hegemonic, orthodox and expected sporting masculinity, David does not feel he has permission to construct or present him self as an emotional being through the kinds of stories he tells. In contrast, in the context of the research interview that invites and encourages an inclusive form of masculinity, David breaks his narrative silence and chooses to tell a very different story.

The different narrative environments described above and the way that these invite the telling of some stories but not others has consequences for those involved. Relevant here is the work by Wasylkiw and Clairo (2016) that focused on what they call 'traditional masculinity' in western societies as a predictor of men's attitudes toward seeking help for mental health issues. In their comparison of a group of male intercollegiate athletes against a comparison group of men not involved in intercollegiate sport, they found that the former scored higher on masculine norms and reported more negative attitudes toward help seeking. For them, this finding is not surprising given that attitudes toward help seeking are antithetical to the norms and values associated with traditional masculinity and so those who endorse traditional masculinity, are less likely to seek help. This has implications for David's 
mental health and well-being. For example, David's story framed within notions of traditional, orthodox, hegemonic, or expected sporting masculinities and associated athletic identity has little space in it for self-compassion, the development of which according to Reis et al. (2015) is particularly beneficial for coping with emotionally difficult sport situations in a way that provides for a healthier, more positive overall sporting experience.

There are also consequences for David in the way that the story he tells about Armstrong demonises him as makes him the villain of the piece. In this process Armstrong is positioned as an autobiographical, affectively self-contained and autonomous 'l'. By doing so, in Bahktin's (1984) terms, David is able to 'finalise' Armstrong as an inherently 'bad' person with no redeeming features or possibility for growth and development. In combination, this acts as a form of narrative foreclosure as described by Freeman (2000: 90) which, in this case, involves the premature conviction that Armstrong's life story has effectively ended and so 'there is no more to tell; there is no more than can be told,' and so there is nothing more to be learned. His future becomes a foregone conclusion in which he is destined to live out a prescripted villain plot-line. Thus, for Armstrong, and other athletes who find themselves in similar sets of circumstance, narratives of forgiveness, reconciliation, atonement or redemption are not offered to them as they are deemed untellable and unlistenable to by athletes like David.

Adherence to the villain narrative informed by the myth of autonomy and the illusion of self-determination, also has the effect of deflecting David's attention away from his complicity in the Armstrong story, and absolving him as an ardent fan with his intense affective attachments, investments and loyalties of any responsibility he might have in the construction and maintenance of sporting heroes as a cultural 
phenomenon. Such heroes are expected to be 'natural' athletes who are chemically 'clean' and lead exemplary lives both within and beyond the domain of sport.

Regardless of the ambiguity and contestation surrounding the concept of the 'natural' and 'clean' athlete, the notion of a flawless athlete is unrealistic and unattainable. Ironically, Armstrong acknowledges this in his interview with Winfrey when he tells her that 'this story was perfect for so long,' but that it was simply impossible to live up to the unflawed picture. He admits he played a major part in constructing this story but realised that as it gained momentum he could not control it as he could control other aspects of his life. He concluded, 'Now the story is so bad it's so toxic.'

The impossibility of living up to an unflawed picture and the consequences that follow a flaw being detected is a vulnerability shared by any sporting hero. This impossibility also means that those who construct such idealised sporting heroes will always run the risk of disappointment and betrayal. In relation to this, it is interesting to note that during an interview David stated that one way in which he might resolve the pain caused by the Armstrong confession was to develop affective attachments, investments and loyalties in new cycling sporting heroes, such as, Bradley Wiggins. Since David made this statement question marks have been raised regarding the therapeutic use exemptions given to Wiggins at the height of his racing career, it is likely that his story isn now a source of trouble for David and the competitive cycling community and that the same narrative strategies will be adopted to cope with this trouble.

Finally, the villain narrative and the demonising of Armstrong as an inherently 'bad' person, acts to focus David's attention on individual 'faults' and deflect his attention away from the dopogenic environment that frames the lives of professional cyclists. Such an environment for Backhouse, Griffiths and McKenna (2018) 
involves the sum of influences produced by the surroundings, opportunities and conditions that promote anti-doping rule violations (ADRVs). They emphasise that local level factors (e.g. team, sports clubs, home, neighbourhood, school), work alongside structural factors (e.g. education systems, national and international sport organisations, health systems, government policies), and societal attitudes and beliefs to create the 'dopogenic' milieu. Focusing on the dopogenic environment, they argue, shifts attention away from a focus on individual morality, ethics and shortcomings toward the powerful interactions between individuals, their social networks and the structures that direct how athletes live and make decisions. For David, any acknowledgement of the such an environment would be problematic as it presents a direct challenge to his villain narrative by offering the possibility of restorying Armstrong, and others like him, as a victim rather than a villain.

Alongside the reflections offered above, it needs to be emphasised that the story told by David about the Armstrong confession and his reaction to it allows him to hold his own in, what for him, are difficult and stressful circumstances. This does not mean, however, that he is living well with this story or that the story is being kind in the ways it acts upon him. As Frank (2012: 46) reminds us, holding one's own is a response to vulnerability and in this response 'the stories that people know set the parameters of what they can imagine as their own to hold.' This raises questions about the narrative resources made available to people like David, how they operate and circulate in specific settings, how this shapes what they imagine as their own to hold in the first place, and what the consequences are for self and others involved in the process.

Such imaginings, as we have illustrated, can be fuelled by intense affective attachments, investments and loyalties in which material biographical objects and 
the development of a strong athletic identity play an important role over time in sustaining the narrative habitus. If this is the case, then these imaginings at both the individual and collective level can also play a part in changing the narrative habitus. As Frank (2010: 58) reminds us, "habitus can be predisposing, but predisposition is never determination.' He emphasises that despite its durability the narrative habitus is neither fixed nor static but is constantly changing, albeit slowly, and that changes in this habitus can be willed. This potential for change is hinted at in David's willingness in the interview situation to tell an emotional story that is supressed and silenced in other sport-related and family settings. How this potential might be enhanced for David and others like him when they are confronted by narrative trouble in differing sets of circumstance so that alternative stories, as actors that do different things for self and others, can be accessed and told is a topic worthy of further inquiry.

\section{References}

Althusser, L. 1971. Ideology and ideological state apparatuses: Notes towards an investigation. Lenin Philosophy and Other Essays.

Anderson, E. 2009. Inclusive masculinity: The changing nature of masculinities.

London: Routledge.

Anderson, E. 2012. Shifting masculinities in Anglo-American countries. Masculinity and Social Change, 1 (1), 40-60.

Anderson, E. and McGuire, R. 2010. Inclusive masculinity theory and the gendered politics of men's rugby. Journal of Gender Studies, 19 (3), 249-261 
Armstrong, L. (with S. Jenkins) 2000. It's not about the bike: My journey back to life. London: Yellow Jersey Press.

Armstrong, L. (with S. Jenkins) 2003. Every second counts: From recovery to victory. London: Yellow Jersey Press.

Atkinson, P. 2017. Thinking ethnographically. London: Sage.

Backhouse, S., Griffiths, C. and McKenna, J. 2018. Tackling doping in sport: a call to take action on the dopogenic environment. British Journal of Sports Medicine, 52 , 1485-1486.

Bakhtin, M. 1984. Problems of Dostoevsky's poetics. Minneapolis: University of Minnesota Press.

Brewer, B., Van Raatle, J. \& Linder, D. 1993. Athletic identity: Hercules' or Achilles heel? International Journal of Sport Psychology, 24, 237-254.

Brewer, B. \& Petitpas, A. 2017. Athletic identity foreclosure. Current Opinion in Psychology, 16, 118-122.

Brockmeier, J. 2017. Witnessing the impact: 9/11 in everyday and literary stories. In: B. Schiff, A. McKim and S. Patron, eds. Life as narrative. Oxford: Oxford University Press, 283-292.

Chamberlain, K. and Lyons, A. 2016. Using material objects and artifacts in research. In: B. Smith and A. Sparkes, eds. Routledge handbook of qualitative 
research in sport and exercise. London: Routledge, 164-176.

Cubitt, G. 2000. Introduction: Heroic reputations and exemplary lives. In: G. Cubitt and A. Warren, eds. Heroic reputations and exemplary lives. Manchester Manchester University Press, 1-26.

Denzin, N. and Lincoln, Y. 2011. Introduction: The discipline and practice of qualitative research. In: N. Denzin and Y. Lincoln, eds. The Sage handbook of qualitative research (4th edition). London: Sage, 1-19

Gubrium, J. and Holstein, J. 2009. Analysing narrative reality. London: Sage

Farred, G. 2002. Long distance love: Growing up a Liverpool Football Club fan. Journal of Sport \& Social Issues, 26, 6-24.

Frank, A. 2010. Letting stories breathe: A socio-narratology. Chicago, II: University of Chicago Press.s[sp:

Frank, A. 2012. Practicing dialogical narrative analysis. In: J. Holstein and J. Gubrium, eds. Varieties of narrative analysis. London: Sage, 33-52.

istepiFrank, A. 2013. The wounded storyteller: Body, illness, and ethics. 2nd ed. Chicago, II: University of Chicago Press.

Freeman, M. 2000. When the story's over: narrative foreclosure and the possibility 
of self-renewal. In: M. Andrews,, S. Schlater,, C. Squire and A. Treacher, eds. Lines of narrative: Psychosocial perspectives. London: Routledge, 8191

Fullagar, S. 2017. Post-qualitative inquiry and the new materialist turn: Implications for sport, health and physical culture research. Qualitative Research in Sport, Exercise and Health, 9 (2), 247-257.

Gammon, S. 2014. Heroes as heritage: The commoditization of sporting Achievement, Journal of Heritage Tourism, 9, 246-256.

Gilchrist, P. 2006. The politics of totemic sporting heroes and the conquest of Everest. Anthropological Notebooks, 12, 35-52

Goffman, E. 1959. The presentation of self in everyday life. New York:Doubleday

Gubrium, J. and Holstein, J. 2009. Analyzing narrative reality. London: Sage.

Hall, G., Shearer, D., Thomson, R., Roderique-Davies, G., Mayer, P. and Hall, R. 2012. Conceptualising commitment: A thematic analysis of fans of Welsh rugby. Qualitative Research in Sport, Exercise and Health, 4 (1), 138-153.

Hoskins, J. 1998. Biographical objects: How things tell the stories of people's lives. London: Routledge.

Humphries, C. and Smith, A. 2014. Talking objects: towards a post-social 
research framework for exploring object narratives. Organization, 21 (4), 477494.

Kelly, W. 2015. Sport fans and fandoms. In: R. Giulianotti, ed. Routledge handbook of the sociology of sport. London: Routledge, 313-323.

Lamont-Mills, A \& Christensen, S. 2006. Athletic identity and its relationship to sport participation levels. Journal of Science and Medicine in Sport, 9, 472-478.

Lieblich, A., Tuval-Mashiach, R. and Zibler, R. 1998. Narrative research. London: Sage

Lines, G. 2001. Villains, fools or heroes: Sports stars as role models for young people. Leisure Studies, 20 (4), 285-303.

Littler. J, 2008. 'I feel your pain': Cosmopolitan charity and the public fashioning of the celebrity soul. Social Semiotics, 18 (2), 336-345.

McAdams, D. 2006. The role of narrative in personality psychology today, Narrative Inquiry, 16 (1), 11-18.

Monforte, J. 2018. What is in new materialism for a newcomer? Qualitative Research in Sport, Exercise and Health, 10 (3), 378-390.

Norrick, N. 2005. The dark side of tellability, Narrative Inquiry, 15 (2), 323-43.

Ochs, E. and Capps, L. 2001. Living narrative. Cambridge, MA: Harvard University 
Press.

Reis, N., Kowalski, K., Ferguson, L., Sabiston, C., Sedgwick, W. and Crocker, P. 2015. Self-compassion and women athletes' responses to emotionally difficult sport situations: An evaluation of a brief induction. Psychology of Sport and Exercise, 16, 18-25

Riessman, C. 2008. Narrative methods for the human sciences. London: Sage.

Ronkainen, N., Kavoura, A. \& Ryba, T. 2016. A meta-study of athletic identity research in sport psychology: Current status and future directions. International Review of Sport Psychology, 9, 45-64.

Rusu, I. 2013. New stories and the creation of myths: The media portrayal of Lance Armstrong as a modern Icarus. European Scientific Journal, 1, 538-544.

Sandvoss, C. 2005. Fans: The mirror of consumption. Oxford: Polity.

Smith, B. 2017. Generalizability in qualitative research: misunderstandings, opportunities and recommendations for the sport and exercise sciences. . Qualitative Research in Sport, Exercise and Health, http://dx.doi.org/10.1080/2159676X.2017.1393221

Sturm, D. 2011. Masculinities, affect and the (re)place(ment) of stardom in Formula One fan's leisure practices. Annals of Leisure Research, 14, 224-241.

Tracy. S. 2010. Qualitative quality: Eight 'Big-Tent criteria for excellent qualitative research. Qualitative Inquiry, 16 (10), 837-851. 
Walton, C., Coyle, A. and Lyons, E. 2004. Death and football: An analysis of men's talk about emotions. British Journal of Social Psychology, 43, 401-416.

Wellard, I. 2009. Sport, masculinities and the body. London: Routledge.

Wasylkiw, L. and Clairo, J. 2016. Help Seeking in Men: When Masculinity and Self-Compassion Collide. Psychology of Men \& Masculinity, 19, 234-242.

Yar, M. 2014. Crime, deviance and doping: Fallen sports stars, autobiography and the management of stigma. London: Palgrave Macmillan. 